\title{
Central Bank Digital Currency: Models and Risks for Monetary Regulation
}

\author{
Oksana Rumiantsava \\ Department of Currency Circulation, Credit and Stock Market \\ Belarus State Economic University \\ Minsk, Belarus \\ rumyanceva_o@bseu.by \\ Svetlana Osmolovez \\ Department of Currency Circulation, Credit and Stock Market \\ Belarus State Economic University \\ Minsk, Belarus \\ swie1@inbox.ru
}

\author{
Irina Rabyko \\ Department of Currency Circulation, Credit and Stock Market \\ Belarus State Economic University \\ Minsk, Belarus \\ irina_rabyko@mail.ru \\ Marina Markusenka \\ Department of Banking \\ Belarus State Economic University \\ Minsk, Belarus \\ Markusenko@mail.ru
}

\begin{abstract}
The relevance of the emission of digital currency by central banks is due to the proliferation of virtual assets, an increase in the share of non-cash payments, and the rapid development of the fintech sector. Monetary regulators are studying the possibilities of issuing their own digital currency in order to make the most of the capabilities of distributed ledger systems in realizing their goals and objectives. The controversial nature of the issue of digital currency emission by the central bank necessitates additional research on this topic due to the uncertainty of the legal and economic status of virtual assets, problems that may arise during the implementation of monetary policy, and the economic feasibility of introducing such a project at the present stage. The article examines the prerequisites for the emergence of projects of the central bank digital currency (CBDC), the emission model of CBDC, the risks of its practical implementation.
\end{abstract}

Keywords-central bank, virtual assets, central bank digital currency $(C B D C)$, distributed ledger technology (DLT), cash, noncash, financial risk.

\section{INTRODUCTION}

The development of digital innovations in the financial market is ahead of the technological, regulatory and institutional capabilities of the state to influence the financial market and cash flows. The improvement of the distributed ledger technology (DLT) and its spread to all spheres of the economy contributed to the formation of innovative virtual assets that radically change the architecture of the financial market.

The relevance of the study presented in this article is due to the current tendency of central banks of different countries of the world to study the prospects for issuing central bank digital currencies (CBDC, hereinafter referred to as the Central Bank Digital Currencies). This topic is especially relevant now, in the context of the proliferation of virtual assets, and, more recently, after the COVID-19 pandemic, which led to an increase in the trend towards non-cash payments and contactless payments.

\section{METHODS}

General scientific methods of analysis and synthesis were used as research tools, as well as specific research methods such as: monographic method, abstract-logical, calculationgraphic, economic-statistical, comparative financialeconomic analysis, etc.

\section{MAIN PART}

The prerequisites for the formation of the idea of issuing digital currencies of the central bank are a number of longterm trends that developed independently of each other: 1) a gradual decrease in cash in circulation, in particular in Belarus, the share of using cash in payments decreased from 69.3 to $45.1 \%$. This trend is typical for all countries and is associated with the development of financial technologies, the improvement of remote payment services, as well as the systemically implemented policy of the central bank for the transition to cashless settlements. In particular, in Belarus, the share of cash payments in the total volume of payment transactions decreased over the period from 2015 to 2019 years from $69.3 \%$ to $45.1 \%$.

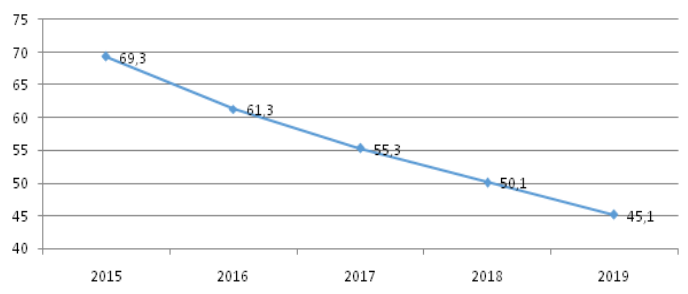

Fig. 1. The share of cash in the total volume of payment transactions in Belarus from 2015 to 2019 [1] 
2) Base rates of central banks of developed countries fell to negative values. Negative base rates create problems in the application of traditional monetary policy instruments, because of which central banks are looking for new effective monetary policy instruments.

TABLE I. BASE INTEREST RATES OF THE CENTRAL BANKS OF THE COUNTRIES OF THE WORLD AS OF SEPTEMBER 30, 2020 [2]

\begin{tabular}{|c|c|}
\hline $\begin{array}{l}\text { Central bank base } \\
\text { interest rate, } \%\end{array}$ & Country \\
\hline In the range of -0.75 to 0 & $\begin{array}{l}\text { Switzerland, Denmark, Japan, Norway, } \\
\text { Sweden }\end{array}$ \\
\hline In the range from 0.1 to 1 & $\begin{array}{c}\text { Great Britain, Israel, Poland, USA, } \\
\text { Australia, Canada, Czech Republic, New } \\
\text { Zealand, South American countries (Peru, } \\
\text { Chile), Korea, Thailand, Hungary Saudi } \\
\text { Arabia }\end{array}$ \\
\hline $\begin{array}{l}\text { In the range from } 1.25 \text { to } \\
2\end{array}$ & $\begin{array}{c}\text { Serbia, Romania, Colombia, Malaysia, } \\
\text { Brazil }\end{array}$ \\
\hline $\begin{array}{l}\text { In the range of } 2.25 \text { to } \\
4.25\end{array}$ & Philippines, China, Russia \\
\hline
\end{tabular}

3) The digitalization of the economy contributes to the emergence of new virtual assets, which are becoming more widespread. Today, the share of crypto assets in circulation is $0.4 \%$ of the total world money supply. However, due to the uneven development of crypto currency markets (large markets operate in the USA, the European Union, Asian countries), the prevalence of crypto currency exchange transactions for the currencies of the US dollar, euro and Japanese yen. The circulation of crypto currencies has some effect on money circulation in North America, Europe, movement interstate cash flows, facilitates speculative unregulated capital outflows in these geographic regions. Thus, according to the estimates of the European Central Bank, the total value of crypto assets of crypto assets in 2018 was $1.2 \%$ of the value of M1 in the Eurozone and $0.8 \%$ of the monetary aggregate M3 [3].

The circulation of crypto currencies poses potential threats to national central banks in terms of the implementation of monetary policy. In theory, the proliferation of virtual assets based on distributed ledger systems could lead to economic agents preferring crypto currencies to traditional bank deposits. There is an opinion that the flow of bank deposits into digital financial assets in conditions of financial instability may reduce the ability of the central bank to achieve the goals of monetary policy [4]. However, the interest of central banks in digital currency is not limited to the prospect of neutralizing threats from decentralized crypto currencies. The interest of central banks in digital currencies is due to the study of the possibilities of distributed ledger technology in realizing the goals and objectives of monetary policy.

In 2019, based on a survey of central banks, various areas of block chain application were identified: issuing central bank digital currencies (CBDC); increasing the reliability of interbank settlements in securities; improvement of payment systems. The use of distributed ledger technology in the issuance and circulation of government bonds or central bank bonds; in combating money laundering and terrorist financing; to create alternative systems for the exchange of data between public or private institutions or within them; for cash management [ 5].

The most widely studied issue by central banks has been the issuance of the central bank digital currency (CBDC). Central banks' interest in CBDC has arisen in connection with the emergence of stable coins and the development in 2019 of Facebook's project to issue a secured virtual asset Libra. The rate of this stable coin was to be fixed and supported based on a basket of fiat currencies (dollar, euro, yen, and pound sterling). Libra's goal was to be used for payments and money transfers via WhatsApp and Facebook Messenger [6].

Stable coins are understood as such virtual assets issued based on distributed ledger technology, the rate of which is tied to the rate of another financial or commodity asset, or to the rate of crypto currency, or their value is supported thanks to the built-in smart contract. Providing stable coins with financial or commodity assets allows you to manage their issue [7].

In the Libra project, Facebook attempted to introduce a new virtual asset, making it a universal means of payment. Therefore, Libra, due to the uncertainty of the boundaries of stable coin regulation, the scale of the project that determines the emergence of a private monetary system, was suspended, and the European Central Bank banned the circulation of stable coins, similar to Libra, until the creation of a mechanism to regulate their circulation [8].

In January 2019, according to the Bank for International Settlements (the BIS), has at least 40 central banks around the world at the present or in the near future planned to carry out research and experiments with digital currency $\mathrm{n}$ In Central Bank (CBDC) [ 5]. A number of central banks are studying this issue at a theoretical level, some central banks have moved on to the practical implementation of CBDC projects. As of mid-July 2020, 36 central banks have published papers looking at retail or wholesale CBDCs. At least three countries (Uruguay, Ecuador and Ukraine) have completed pilot retail CBDC projects. Six more retail CBDCs are currently being piloted in Sweden, South Korea, the Eastern Caribbean Monetary Union, the Bahamas, the PRC and Cambodia [9].

CBDC, according to experts from the Bank for International Settlements, is not a sufficiently definite term that is used to refer to a number of concepts. However, most central banks believe that it is a new form of central bank digital money. Its essential characteristics are that it is the obligation of the central bank, expressed in the existing unit of account, which serves as both a medium of exchange and a store of value. Since banks and credit, institutions already have reserves and accounts at the central bank, the CBDCs are issued for a wide range of users that are new to the economy. Therefore, CBDC is defined as a digital form of money $n$ In Central Bank, which is different from the remnants of traditional backup or current accounts. [10, 4]

In other words, CBDC represents the central bank's obligations, expressed in national payment units, which can serve as a means of exchange (settlement), a measure of value and a means of payment, i.e., perform all the functions of money and operate based on distributed ledger technology. In fact, CBDCs are a form of stable coin backed by central bank assets. In the modern economy, money exists in the forms: cash issued by the central bank and deposits in the form of funds in accounts with the central bank and commercial banks. CBDC is a digital national currency that will circulate in parallel with cash and non-cash money, but exist in the form of a digital code in the block chain system. There are many options for the release of CBDC, which differ in the following parameters: architecture; infrastructure; technology and 
conditions of access; level of anonymity; possibility of application for domestic or cross-border payments.

Currently, central banks are considering two main models of central bank digital currency: wholesale access (for financial institutions only), retail access for a wide range of people. Variants of digital currency models will be determined by its technical implementation: based on tokens in the distributed ledger system, or based on accounts on current accounts, with or without the participation of financial intermediaries [10].

All central banks experimenting with DLT use CBDC control options, where the distributed ledger system operators are free to decide who can be admitted to the central bank's digital currency. Not a single central bank has considered the option of creating a decentralized DLT system, as was done in relation to the bit coin system [9].

The distinction between digital central bank money based on tokens or accounts on accounts determines the technology for their implementation and the form of transaction authentication required in making payments and transfers. The use of token-based money is carried out in a distributed ledger system, in which transactions with tokens will be verified. The use of money using an account mechanism determines the need to identify the identity of the account holder. Therefore, data protection mechanisms differ: when using tokens, the key will be the protection of an electronic wallet, and when using accounts - protection against identity theft. According to Kochergin D. A., Yangirova A. I., in the retail application of CBDC, it is advisable to use digital currency based on tokens, which will give them the characteristics of cash, while for wholesale payments it is possible to use digital currency based on current accounts [11]. The current approbation of the CBDC concept by central banks is based primarily on DLT (distributed ledger technology rather than on traditional technological infrastructure) [9].

Let us look at the main differences in the wholesale and retail CBDC emission models.

In case of implementation of wholesale access (based on tokens), the central bank issues CBDCs for banks and other financial institutions in order to improve interbank settlements and securities turnover. Individuals and legal entities in this model do not have access to CBDC. The wholesale model does not make significant changes in monetary circulation, since the digital currency of the central bank in this case plays the role of a financial asset and a means of payment in the interbank market, and does not essentially differ from banks' reserves in the central bank. In the wholesale model, the central bank's digital currency is represented in the form of its obligation and can be identified as a special type of non-cash money, similar to the banks' reserves in correspondent accounts.

The Bank for International Settlements report noted that the introduction of wholesale CBDC into interbank payment systems could potentially improve efficiency and risk management in settlements, including by new technologies for asset transfer, authentication, accounting, data management and risk management [10].

When implementing a DLT-based wholesale model, the central bank can use the CBDC as a monetary regulation tool. In particular, when buying a digital ruble from a bank, excess reserves will decrease, and, therefore, this will have an impact on the size of the money supply. Therefore, the creation of the interbank CBDC market and the accrual of income on deposits in digital currency will allow the central bank to exert additional influence on the monetary base and strengthen the possibilities of interest rate policy.

The advantages of the wholesale CBDC model are the ability of the central bank to more effectively influence the monetary base and money supply. The use of distributed ledger technology will contribute to the efficiency of settlements in the interbank market, reduce operational and credit risks, since CBDC is an obligation of the central bank. By increasing the transparency of payments and transfers, additional opportunities for the central bank will appear in the implementation of prudential supervision, control over antimoney laundering procedures. The disadvantage of the wholesale CBDC is its limited scope for interbank transactions and clearing.

Projects of the retail model CBDC began to develop in 2016 [9]. The first retail CBDC study was launched by the Central Bank of Sweden (e-krona project) in 2017, and the project was tested in 2020. The relevance of the CBDC study was due to the rapid decline in cash settlements in this country. China in 2020 began testing retail CBDC (e-Yuan) in four cities (Shenzhen, Suzhou, Chengdu and Xiongan) through local businesses and some international companies. [12]

The essence of the CBDC retail model is that the central bank issues digital money, giving individuals and legal entities access to it. In the retail model, CBDCs are like cash; their circulation is decentralized, while the block chain system allows registering all transactions and preventing illegal transactions. In the implementation of the retail model of digital money, several options significantly affect the models of activity of financial intermediaries:

- implementation based on direct access of legal entities and individuals to electronic wallets in CBDC at the central bank. Then the central bank carries out AML / CFT / FROMU procedures, opens wallets for clients and makes settlements on them.

- implementation with the participation of banks, when banks have direct access to electronic wallets with digital currency in the central bank, and act as intermediaries in the opening of electronic wallets to individuals and legal entities. Banks / financial intermediaries in this model carry out AML / CFT / FROMU procedures in relation to clients, provide them with mobile applications for making settlements on wallets in CBDC and initiate requests for opening wallets and settlements on the CBDC platform on behalf of clients [13] .

Given that retail CBDCs directly affect money circulation, it is important to predict in advance the possible impact of a central bank's digital money circulation on monetary policy outcomes. With the introduction of CBDC, economic entities will distribute their funds based on needs between cash, accounts in commercial banks and e-wallets in the CBDC. In this case, there may be situations where individuals can transfer their deposits from banks to electronic wallets at the central bank.

The central bank will have to take into account retail CBDCs in the composition of the money supply, and accordingly, the structure of monetary indicators, the composition of the money supply, as well as monetary policy instruments that can influence it, will change. Since retail 
CBDC is similar to cash, it will not be charged a percentage. The central bank will be able to regulate the volume of banks' reserves using interest rate policy.

To implement CBDC, it is necessary to assess its economic feasibility. We believe that for countries with emerging financial markets it is necessary to assess the financial risks of the CBDC issue. The digitalization of central bank operations will primarily entail an increase in the cost of ensuring the cybersecurity of the block chain digital currency system. Thus, global losses from cybercrime in the short term could amount to 600 billion US dollars per year, or $0.8 \%$ of global GDP. Central banks can be harmed by cybercriminals if this risk is not adequately addressed. An attack on the central bank's block chain system will endanger the country's financial system [14].

According to the 2019 World Economic Forum's Global Risks Report, data fraud and cyber-attacks are the fourth and fifth global risks that every organization faces. In terms of their importance, these risks are equated to environmental problems [15].

The emergence of a new type of money will affect the issues of their legal classification: what money should be considered CBDC, cash or non-cash. This issue will be especially acute in the implementation of the retail model of central bank digital money. If transactions with digital money of the central bank are carried out online and offline, and by its characteristics, such money will be recognized as an analogue of cash. The question will arise about the development of conditions for transactions with digital money for legal entities so that there is no danger of outflow of funds of deposits of legal entities from bank accounts.

One of the issues currently being studied is also the impact of CBDC on the transmission mechanism. In the economic literature, the transmission mechanism is understood as the impact of monetary policy measures on economic activity, accumulation, consumption, and inflationary processes. In other words, monetary instruments affect economic processes in the real sector by a mechanism. From the structural point of view, the transmission mechanism is a set of channels through which the monetary impulses generated by the central bank affect the main macroeconomic variables (GDP, employment, inflation, balance of payments), reflecting the main goals of the state's economic policy. At the same time, today there is no consensus on the number and classification of channels of monetary policy impact on the real sector of the economy.

The factors influencing the transmission mechanism on the economy are diverse and depend on specific institutional conditions, the behavior of economic agents, and the efficiency of the country's financial system. This is the weak initial financial condition of economic agents; a high degree of dollarization of the economy. Low level of capitalization of national banking systems, their vulnerability to stress as a result of actions of internal and external banking risks; lack of long-term capital markets and mechanisms to regulate the relationship between short-term and long-term interest rates; forced in such conditions state subsidizing of certain priority credit projects, etc. In addition, the adopted procedure for conducting monetary policy, the established practice of using not only economic, but also administrative monetary methods are important.

The most often distinguished channel is the interest rate channel, the channel for transmitting monetary impulses through asset prices (which include, as a rule, stock market prices, real estate prices, the exchange rate), and the credit channel. The impact of changes in monetary policy on the economy through the exchange rate of the national currency is distinguished into a separate channel. Many authors, along with the interest rate channel, the channel of asset prices (including the exchange rate) and the credit channel, distinguish the "money channel", "welfare channel", "balance channel".

The models of the transmission mechanism are built taking into account the prevailing economic conditions and contain variables that have the most stable relationships and interdependencies of economic agents. An unbalanced economy with a low level of confidence in the national currency and the banking system significantly changes the nature of the transmission mechanism, and, accordingly, sets an acceptable monetary policy toolkit in order to achieve the goals outlined by the state's macroeconomic policy.

With the introduction of retail digital currency into monetary circulation, banks will for some time adjust to liquidity management due to the processes of redistribution of funds between bank deposits and electronic wallets in digital currency. To date, it is difficult to assess the degree of decline in the bank's resources due to the outflow of deposits to electronic wallets. Obviously, non-deposit sources, such as debt instruments of the financial market, will gain significance in attracting resources by banks. Banks will have to change their business models, focus not only on financial intermediation in the field of capital redistribution, but also on the performance of a wide range of related intermediary services in the field of finance (trust management of financial assets, settlement operations, etc.)

In the long-term period of adaptation of the financial system to the circulation of digital currency and an increase in its distribution among the population, the channels of the transmission mechanism will change. The influence of the interest rate and monetary channels will increase due to the impact through the new instruments of the central bank on the banks' reserves in the central bank and the structure of their resources. Obviously, non-monetary transmission channels, for example, the channel of inflationary expectations, will gain importance.

There are points of view that the introduction of the digital ruble can limit the risks of redistributing funds of economic entities into digital currencies of other central banks, thus contributing to the preservation of the attractiveness of the national currency [13]. In our opinion, this is a controversial opinion, since other virtual assets are considered from the point of view of investment and speculative attractiveness, and the national CDBC will be considered as a means of payment and settlement, a measure of value, a store of value.

It should be noted that the recognition of the need for CBDCs by the central banks of countries makes it possible to assess the risks associated with their issue and manage them. Since risk can be the result of both action and inaction, if we do nothing, then we still risk, and even more than if, we recognize and assess the risk. Recognizing the risks of virtual assets allows the development of tools for assessing the corresponding types and risk factors. If the central bank recognizes the SBDC, will integrate criteria for assessing the risks associated with this process, and a system for monitoring systemic risk, in the legal field states. Failure to recognize 
CBDCs by the central banks of the countries, in our opinion, will increase the risks of circulation of virtual assets. First, the risks of money laundering and the impact of unaccounted cash flows on the country's money supply will increase. From the standpoint of risk assessment, it is very important to determine the owner of the risk. In the theoretical concept of risk, the owner of the risk is the owner of the process most interested in managing the selected risk. This interest is because the assessment and elimination of a specific risk contributes to the achievement of the goal of the process. Recognition SBDC $n$ In Central Bank determines the risk of the owner handling virtual assets in the face of $n$ In Central Bank, is interested in the purity of cash flows, and allows to preserve this purity. When the non-recognition of SBDC $\mathrm{n}$ In Central banks, there are several risk owners, making it difficult to assess and manage risks.

\section{CONCLUSION}

CBDC represents the obligations of the central bank, expressed in national payment units, which can serve as a means of exchange (settlement), a measure of value and a means of payment, that is, perform all the functions of money and operate on the basis of distributed ledger technology.

The planning of the CBDC issue by central banks is due to the search for new tools to influence monetary indicators, testing the capabilities of the distributed ledger technology, and control over the circulation risks of virtual assets.

Recognition of CBDC by central banks will reduce the risks of virtual assets turnover, control domestic and cross-border cash flows, and increase the transparency of payments and transfers.

\section{REFERENCES}

[1] Share of cash in total payment transactions in Belarus from 2015 to 2019. URL: https://www.statista.com/statistics/1112450/cash-use-inbelarus/ (accessed 02.10.2020)

[2] Central bank policy rates, The Bank for International Settlements URL: https://www.bis.org/statistics/cbpol/cbpol_2010.xlsx (accessed 10.10.2020).

[3] Crypto-Assets: Implications for financial stability, monetary policy, and payments and market infrastructures, European Central Bank. URL:

https://www.ecb.europa.eu/pub/pdf/scpops/ecb.op223 3ce14e986c.en .pdf (accessed 10.10.2020), p. 11.

[4] Andryushin S.A., "Monetary systems: from origins to crypto currencies", Monograph, Moscow.: Publishing house LLC "Sam Polygraphist", 2019, p. 214.

[5] Central Banks and Distributed Ledger Technology: How are Central Banks Exploring Block chain today? URL: http: //www3.weforum.org/docs/WEF_Central_Bank_Activity_in_Blockch ain_DLT.pdf (accessed 10.10.2020), pp. 4-7.

[6] Facebook has registered the company Libra Networks. URL: https: // happycoin. Club / facebook - zaregistriroval - kompaniyu - libra networks (accessed 10.10.2020).

[7] D. Bullmann, J. Klemm, A., Pinna, In search for stability in cryptoassets: are stable coins the solution?, European Central Bank, URL: https://www.ecb.europa.eu/pub/pdf/scpops/ecb.op230 d57946be3b.e n.pdf (accessed 10.10.2020).

[8] The EU has banned the circulation of the Facebook Libra crypto currency.

URL: https://www.rbc.ru/economics/06/12/2019/5de984cc9a7947420136eb 08 (accessed 10.10.2020).

[9] R. Auer., G. Cornelli, J. Frost, Rise of the central bank digital currencies: drivers, approaches and technologies?, URL: https://www.bis.org/publ/work880.pdf (accessed 10.11.2020).
[10] Central bank digital currencies, Committee on Payments and Market Infrastructures BIS. URL: https://www.bis.org/cpmi/publ/d174.pdf (accessed 10.10.2020), p. 7-8.

[11] D.A. Kochergin, A.I. Yangirova, "Central bank digital currencies: key characteristics and directions of influence on the monetary and payment systems", Finance: theory and practice, v. 23, No 4, 2019, p. 80-98.

[12] C. Nolting, G. Heinz, S. Köhling, Central bank digital currencies. URL: https: //www.db.com/newsroom_news/CIO_Special_Central_bank_digital_currencies_-_Money_reinvented_-_WM.pdf (accessed 10.10.2020), p. 5.

[13] Digital ruble. Report for public consultations. URL: https://cbr.ru/analytics/d_ok/dig_ruble/ (accessed 10.10.2020), pp. 2230.

[14] J. Lewis, Economic Impact of Cybercrime - No Slowing Down, Center for strategic and international studie.. URL: https://csis-websiteprod.s3.amazonaws.com/s3fs-public/publication/economic-impactcybercrime.pdf (accessed 10.10.2020).

[15] The Global Risks Report 2019. URL: www.weforum.org/docs/WEF_Global_Risks_Report_2019.pdf. (accessed 10.10.2020). 